\title{
Investigate the Ability of Bankruptcy Prediction Models of Altman and Springate and Zmijewski and Grover in Tehran Stock Exchange
}

\author{
Abolfazl Aminian ${ }^{1^{*}}$ \\ Hedayat Mousazade ${ }^{2}$ \\ Omid Imani Khoshkho3
}

\begin{abstract}
${ }^{1}$ Faculty of Accounting, Department of Management, Economics and Accounting, Payame Noor University (PNU),
P.O. Box, 19395-3697, Tehran, Iran.Email: Amin8481@gmail.com

2 Msc Accounting, Department of Business Management, Master of Business Management,

Health Care \& Social Security Administration, Karaj, Iran.Email: hedayat_m255@yahoo.com

${ }^{3}$ Faculty of Accounting, Department of Management, Economics and Accounting, Payame Noor University (PNU),
\end{abstract}

P.O. Box, 19395-3697, Tehran, Iran.Email: imani4599@gmail.com

\section{Doi:10.5901/mjss.2016.v7n4s1p208}

\section{Abstract}

\begin{abstract}
The recent bankruptcies of large companies at the international level and fluctuations in the Iran stock exchange shows that the need for tools to assess the financial ability of companies. One of these tools is using the bankruptcy prediction models. Due to this necessity, the main purpose of this study was to determine the amount of model'sefficiency of Altman, Springate, Zmijewski and Grover in predicting bankruptcy situation of listed companies in the Tehran Stock Exchange and compares the results of the models; in order to fulfill this goal has been developed eight hypotheses. The statistical population and the sample size of this study are to include 35 companies from textile and ceramic and tilecompanies listed on the Tehran Stock Exchange during the period 2008 to 2013. In this study, after determining the normal distribution of data by using of correlation tests, any of the study hypotheses are being tested and to respond to research hypotheses, we used regression analysis.Also, by using correlation analysis to examine the significance of each of the models of Altman, Springate, Zmijewski and Grover and to find the model was used by the method of multiple linear regressions for panel data.Finally, after the test, all the hypotheses were confirmed and the results showed that "in the five years of the study to predict the company's bankruptcy, respectively the model of Grover, Altman, Springate and Zmijewski have the better ability to predict financial crises.
\end{abstract}

Keywords: Bankruptcy, Altman, Springate, Zmijewski, Grover

\section{Introduction}

The rapid and increasedgrowth of science and technology in the present age has been caused the complexity of human relations, especially economic and trade relations than in the past. The progress of science and technology turned economy and trade into a new phase, so that companies and past small economic enterprises have become to public joint stock companies and even multinational in worldwide.This transformation of the economy and trade, on the one hand has led the small companies have been out of the competition and on the other hand, the large companies that were not able to compete with other companies in their industry are faced with the problem of hedging activities or financial crisis and finally bankruptcy.On the other hand, the cycle of the competition, which had been the factor in much greater company'sdevelopment (in terms of number of shareholders, expanding the size and scope) is more the gap between the suppliers of financial resources (shareholders, investors, creditors and lenders) and corporate management, in terms of control and direct supervision of the company. These factors led to company's financial resource suppliers concern, because in fact, financial resource suppliers: Firstly, they were not able to control and direct supervision on the company. Secondly, they could not predict the company's financial situation in the future.At this stage, financial analysts came to help investors; they are using different methods conducted to evaluate corporate shares and analysis of the financial situation in the future. Financial ratios considered one of the most important tools in predicting the hedging activity and financial crises. 


\section{Problem Statement}

Today, the rapid development of technology and extensive environmental changes has given momentum to the economy and the increasing competitiveness of enterprises limits access to benefits and increases the probability of bankruptcy.Owners, managers, investors, business partners and creditors, as well as state institutions are interested to assess the financial situation of a company and its tendency to bankruptcy. Thus, financial decision-making than in the past have been more strategic.In the financial decisions in an institution, the real and appropriate scientific criteria are required for each institution. One indicator for this objective is the correct evaluation the possibility of the bankruptcy of companies. Financial ratios are one of the tools to analyze financial problems, which researchers were able by combining these ratios provide the multivariablemodels to predict bankruptcy.Bankruptcy prediction models are one of the techniques and prediction tools of the company future status, which estimates the probability of bankruptcy with a group combination of financial ratios.

\section{Research History}

In the last 35 years, the subject of "company's bankruptcy prediction" as one of the major themes of management has become in the finance literature.Researchers have tried in many scientific research based on available information and statistical techniques to discover the best bankruptcyprediction models. Each of the researchers in the above-mentioned research has reached conclusions that here referred to the results of some of them researchbriefly:

- Altman is the first person introduced the multivariate bankruptcy prediction models. He by using multiple discriminate analysis methods and the use of financial ratios as independent variables was looking for a firm's bankruptcy prediction. He presented his famous pattern under the title of z-score, which is known to commercial bankruptcy prediction. With this method among the 22 financial ratios, which in his opinion were the best ratios to bankruptcy prediction, he has selected 5 ratios. Altman with combining this 5 ratio presented model, which, according to him were the best.

- Springate continued Altman studies and the use of audit analytics for selecting 4appropriate financial ratios, which was included working capital to total assets, profit before interest and taxes to total assets, profit before tax to current debt, sale to total assets among the 19 ratio, which had the best ratio to identify healthy and bankrupt companies and after its tests, provided a model in 40 companies, which achieved to 92.5 percent correct predictions. (Springate, 1978, p. 128).

- Ohlson to create your pattern, use of logistic analysis and tested their sample in 105 bankrupt companies and in 2058 non-bankrupt companies. He, in own pattern used from 9 independent variable, his pattern achieved to 85.1 percent correct predictions. (Ohlson, 1980, p. 121).

- Zmijewski use of financial ratios of liquidity, leverage and performance to provide them proper pattern. This ratio had not been selected based on the theoretical, but was more based on his experiences in his previous studies. Zmijewski pattern was established based on a sample including 40 bankrupt companies and 800 nonbankrupt production companies and achieved to 86.14 percent correct predictions. (Zmijewski, 1984, p. 22).

- Shirata after reviewing previous studies receive the results of previous studies in Japan due to a low number and limited number of cases not applicable to production companies with assets of nearly identical.Shirata to fix these weaknesses presented a comprehensive model to predict bankruptcy for all types of companies of production, trade and services with each capital value.Shirata for his model usedby the multiple discriminate analysis method. His statistical sample was includedof 686 bankrupt companies and 300 non-bankrupt companies in the period 1986 to 1996. The results showed that his model can predict bankruptcy with an accuracy of more than 86.14 percent. (Shirata, 1998, p. 429).

- Soleymani Amiri in his study entitled to investigate the prediction bankruptcy indices in environmental conditions of Iran, paid to provide a model for predicting bankruptcy in Iran. His pattern was composed of 15 independent variables that, some of which were financial ratios and some were qualitative variables. In this model, the value of $z$ is closer to zero, the probability of bankruptcy is more, and the value of $z$ is closer to number one theprobability of bankruptcyis less. (Mehrani, 2005, p. 110).

- Hasan Asgari in their study paid to review the performancepatterns of Springate, Zavgin and Falmerto predicting bankruptcy the listed companies in the Tehran Stock Exchange and came to the conclusion that at a confidence level of $90 \%$, the Springate pattern compared to Falmer and Zavgin patterns is more accurate for predicting the company'sbankruptcy. (Asgari, 2008, p. 1) 


\section{The Research Analytical Models and Methods of Measuring Variables}

In the analysis the research variables are divided into two groups with different entities. The first group is the independent variables and the second group is dependent variables, which could be qualitative or quantitative.

\subsection{Altman Pattern}

$$
\begin{aligned}
Z^{\prime}=0.717 X 1+0.847 X 2+3.108 X 3+0.42 X 4+0.987 X 5 \\
\\
X_{1}=\text { Total Assets / Working Capital } \\
X_{2}=\text { Total Assets / Retained Earnings } \\
X_{3}=\text { Total Assets / Income before Interest and Taxes } \\
X_{4}=\text { Book Value of Debt / Market Value of Equity } \\
X_{5}=\text { Total Assets / Total Sales }
\end{aligned}
$$

\subsection{Springate Pattern}

$$
\begin{aligned}
Z=1.03 X_{1} & +3.07 x_{2}+.66 x_{3}+.4 x_{4} \\
X_{1} & =\text { Ratio of working capital to total assets } \\
& X_{2}=\text { Earnings before deducted interest and taxes to total assets } \\
X_{3} & =\text { Ratio of net profit before deducted taxes to current liabilities } \\
X_{4} & =\text { Sales ratio to total assets }
\end{aligned}
$$

\subsection{Zmijewski Pattern}

$Y=-4.3-4.5 x_{1}+5.7 x_{2}-.004 x_{3}$

$X_{1}=$ Ratio of net income to total assets

$X_{2}=$ Ratio of total debt to total assets

$X_{3}=$ Ratio of current assets to current liabilities

\subsection{Grover Pattern}

$$
\begin{aligned}
\text { Score } & =1.650 \mathrm{X} 1+3.404 \mathrm{X} 2-0.016 \mathrm{ROA}+0.057 \\
& \mathrm{X}_{1}=\text { Total Assets } / \text { Working Capital } \\
& \mathrm{X}_{2}=\text { Total Assets } / \text { Income before Interest and Taxes } \\
& \mathrm{ROA}=\text { Total Assets } / \text { Net Profit }
\end{aligned}
$$

\subsection{How to Assess Patterns}

Table 1:

\begin{tabular}{|l|c|}
\hline Hypotheses Classification & Significant Condition \\
\hline Strong Significant & $\mathrm{P}<\% 1$ \\
\hline Average Significant & $\% 1>\mathrm{P}<\% 5$ \\
\hline Weak Significant & $\% 5>\mathrm{P}<\% 10$ \\
\hline No Significant & $\mathrm{P}<\% 10$ \\
\hline
\end{tabular}

\section{Research Hypotheses}

- First hypothesis: Altman model is significant as a model to predict financial crises.

- Second hypothesis: Springate model is significant as a model to predict financial crises.

- Third hypothesis: Zmijewski model is significant as a model to predict financial crises.

- Fourth hypothesis: Grover model is significant as a model to predict financial crises.

- Fifth hypothesis: Altman model has better ability to predict financial crises than the models of Springate, Zmijewski and Grover.

- Sixth hypothesis: Springate model has better ability to predict financial crises than the models of Altman, 


\section{Zmijewski and Grover.}

- Seventh hypothesis: Zmijewski model has better ability to predict financial crises than the models of Altman, Springate and Grover.

- Eighth hypothesis: Grover model has better ability to predict financial crises than the models of Altman, Springate and Zmijewski.

\section{Population and Statistical Sample}

To test the research hypotheses should be selected the target population, in such a way that can be collected the desired information with trust and confidence.Population, which include all real or imagined individuals that the researcher is interested generalizing the results to them. The advantage of selecting a sample of a population is to prevent from researchers wasting time and save money.Through the study of relatively small samples and using a correct sampling method and accepting small amounts of error, researcher will reach to the results almost right. Variety of populations that the research usually is selected research sample, in which, depending on the research can be limited or unlimited.The population of this research is the textile and ceramic and tile companies listed on the Tehran Stock Exchange. In this study, for the fit bankruptcy prediction pattern, there was a need to two group'sinformation of bankrupt and non-bankrupt companies. Textile companies, because in previous research in this area were identified as bankrupt companies, as well as in the study were selected as bankrupt companies. Also ceramic and tile companies, due to the monopolistic market of products and low traction of the products were considered as an average industry to supply samplesof non-bankrupt companies.Due to lack of access to accurate information of financial statements of bankrupt and non-bankrupt companies outside the Tehran Stock Exchange, the study population is selected from among listed companies in Tehran Stock Exchange. Also in this study, the statistical sample was taken equal to statistical population. Thus, the all companies of population's member, which have the following conditions, are in statistical sample:

a. Before 2008, were accepted in Tehran Stock Exchange.

b. Its financial statements are submitted to the exchange in the period 2008 to 2013.

\section{Criterion for Determining Bankruptcy}

In order to categorize companies into two non-bankrupt and bankrupt categories is used by default Article 141 of the Commercial Code.According to the article: "If as a result of losses incurred eliminate at least half of the company's capital, the Board of Directors is obliged to immediately invite the owner of the shares for the extraordinary general meeting to be about passion and vote the subject to liquidation or survival Company". Thus, if a company within the time period from 2008 to 2013 is subject to Article 141 of the Commercial Code is bankrupt and if not is non-bankrupt company.

\section{Research Results}

Table 2. Altman model estimation results

\begin{tabular}{|c|c|c|c|c|}
\hline & Coefficient & Standard deviation & T Statistics & Probability \\
\hline $\mathrm{C}(1)$ & -0.51 & 0.43 & -1.17 & 0.23 \\
\hline $\mathrm{C}(2)$ & 0.98 & 0.03 & 27.79 & 0.000 \\
\hline $\mathrm{C}(3)$ & -0.006 & 0.02 & -0.24 & 0.80 \\
\hline $\mathrm{C}(4)$ & 1.16 & 0.32 & 3.57 & 0.000 \\
\hline $\mathrm{C}(5)$ & 0.15 & 0.27 & 0.57 & 0.56 \\
\hline $\mathrm{C}(6)$ & 1.12 & 0.34 & \multicolumn{2}{|c|}{0.92} \\
\hline \multicolumn{2}{|l|}{ Determination Coefficient (R2) } \\
\multicolumn{2}{|l|}{ Durbin-Watson Statistic } & \multicolumn{2}{|c|}{1.56} \\
\hline
\end{tabular}


Table 3. Springatemodel estimation results

\begin{tabular}{|c|c|c|c|c|}
\hline & Coefficient & Standard deviation & T Statistics & Probability \\
\hline $\mathrm{C}(1)$ & 1.24 & 0.78 & 1.57 & 0.11 \\
\hline $\mathrm{C}(2)$ & 1.59 & 0.09 & 16.31 & 0.000 \\
\hline $\mathrm{C}(3)$ & 5.34 & 0.93 & 5.73 & 0.000 \\
\hline $\mathrm{C}(4)$ & 2.69 & 2.82 & 0.95 & 0.341 \\
\hline $\mathrm{C}(5)$ & 0.03 & 0.21 & 0.16 & 0.866 \\
\hline \multicolumn{2}{|l|}{ Determination Coefficient (R2) } & \multicolumn{2}{|c|}{0.84} \\
\hline \multicolumn{2}{|l|}{ Durbin-Watson Statistic } & \multicolumn{2}{|c|}{} \\
\hline
\end{tabular}

Table 4. Zmijewskimodel estimation results

\begin{tabular}{|c|c|c|c|c|}
\hline & Coefficient & Standard deviation & T Statistics & Probability \\
\hline $\mathrm{C}(1)$ & 6.98 & 5.05 & 1.38 & 0.16 \\
\hline $\mathrm{C}(2)$ & 1.33 & 2.99 & 0.44 & 0.65 \\
\hline $\mathrm{C}(3)$ & -1.15 & 0.33 & 3.48 & 0.000 \\
\hline $\mathrm{C}(4)$ & -5.16 & 4.42 & -1.16 & 0.24 \\
\hline \multicolumn{2}{|l|}{ Determination Coefficient (R2) } & \multicolumn{2}{|c|}{0.09} \\
\hline \multicolumn{2}{|l|}{ Durbin-Watson Statistic } & \\
\hline
\end{tabular}

Table 5. Grovermodel estimation results

\begin{tabular}{|c|c|c|c|c|}
\hline & Coefficient & Standard deviation & T Statistics & Probability \\
\hline $\mathrm{C}(1)$ & 1.85 & 0.08 & 21.73 & 0.000 \\
\hline $\mathrm{C}(2)$ & -0.99 & 0.01 & -95.33 & 0.000 \\
\hline $\mathrm{C}(3)$ & 0.89 & 0.08 & 10.42 & 0.000 \\
\hline $\mathrm{C}(4)$ & 0.003 & 0.002 & 1.54 & 0.125 \\
\hline Determination Coefficient (R2) & \multicolumn{2}{|c|}{0.98} \\
\hline
\end{tabular}

Table 6. Compare the estimated models

\begin{tabular}{|l|c|c|}
\hline Model & Determination Coefficient (R2) & Priority \\
\hline Altman & 0.92 & 2 \\
\hline Springate & 0.84 & 3 \\
\hline Zmijewski & 0.09 & 4 \\
\hline Grover & 0.98 & 1 \\
\hline
\end{tabular}

Finally, according to the results, we can pay confirm or reject the research hypotheses:

To respond to the research hypotheses has been used regression test. By correlation test was used to evaluate the significance of each of the models of Altman, Springate, Zmijewski and Grover and to find the research model was used multiple linear regression for panel data.

First hypothesis: Altman model is significant as a model to predict financial crises.

According to the obtained results was significant the Altman model and confirmed the first hypothesis.

Second hypothesis: Springate model is significant as a model to predict financial crises.

According to the obtained results was significant the Springate model and confirmed the second hypothesis.

Third hypothesis: Zmijewski model is significant as a model to predict financial crises.

According to the obtained results was significant the Zmijewski model and confirmed the third hypothesis.

Fourth hypothesis: Grover model is significant as a model to predict financial crises.

According to the obtained results was significant the Grover model and confirmed the fourth hypothesis.

Fifth hypothesis: Altman model has better ability to predict financial crises than the models of Springate, Zmijewski and Grover.

Sixth hypothesis: Springate model has better ability to predict financial crises than the models of Altman, Zmijewski and Grover. 
Seventh hypothesis: Zmijewski model has better ability to predict financial crises than the models of Altman, Springate and Grover.

Eighth hypothesis: Grover model has better ability to predict financial crises than the models of Altman, Springate and Zmijewski.

To confirm or reject the hypotheses of fifth to eighth can be according to the coefficient of determination obtained for each of the models of Altman, Springate, Zmijewski and Grover, it stated that: respectively, the models of Grover, Altman, Springate and Zmijewski, have the better ability to predict financial crises.

\section{Conclusion}

This study was investigated to compare the ability the models of Altman, Springate, Zmijewski and Grover to predict bankruptcy of the companies listed on the Tehran Stock Exchange in the realm of time from 2008 to 2013. For this purpose, we were raised eight main hypotheses and to test each of the hypothesesdefine two statistical hypotheses of $\mathrm{HO}$ and $\mathrm{H1}$. As a result rejected the HOhypothesis in all eight hypotheses from hypotheses groups and confirmed $\mathrm{H} 1$ hypothesis in all eight hypotheses from hypotheses groups.

According to the Altman model, which the results shown in Table2, we see that the variables of $X_{1}, X_{3}$ and $X_{5}$ are significantly in Altman model. On the other hand, the coefficient of determination obtained is equal to 0.92 , which states that the variables in the model can represent $92 \%$ of the changes in the Altman model.

According to the Springatemodel, which the results shown in Table3, we see that the only variables of A and B in the model are significant. On the other hand, the coefficient of determination obtained is equal to 0.84 , which states that the variables in the model can represent $84 \%$ of the changes in the Springate model.

According to theZmijewski's model, which the results shown in Table4, we see that the only $X_{2}$ variables in the model are significant. On the other hand, the coefficient of determination obtained is equal to 0.09 , which states that the variables in the model can show only9\% of the changes in the Zmijewski's model.

According to the Grovermodel, which the results shown in Table5, we see that all the variables, except the ROA variable in the model are significant. On the other hand, the coefficient of determination obtained is equal to 0.98 , which states that the variables in the model can represent $98 \%$ of the changes in the Grovermodel.

\section{Suggestions}

According to the main hypothesis of the fifth to the eighth that the researcher has claimed: "Among the models of Altman, or Springate, or Zmijewski, or Grover, which one will have a better ability to predict financial crises" that is based on the test hypothesis result, it was demonstrated that respectively, the model of Grover, Altman, Springate and Zmijewski have the better ability to predict financial crises.Companies bankruptcy prediction of the Grover model compared to the models of Altman, Springate and Zmijewski's show better results, and since investors are always looking for knowledge the suitable situationfor investment, and managers are interested to assess the weaknesses and future threats and take the necessary decisions in the face of these threats, it is suggested that the use of the Grover model as a tool for predicting bankruptcy or continuity of the companies and accordingly to make rational decisions.

\section{References}

Eftekhari, J, 2000, "Business Law -4- (theoretical and practical) bankruptcy andtreatment of bankruptcymatters", Ghoghnoos Publishing. 2.Ahmadi Kashani, S.A, 2005, "bankruptcy prediction model in equipment and home appliances industry", master's thesis, Islamic Azad University, Central Tehran Branch.

Pourmehr, S., 2007, "investigate the feasibility use of Springate and Zmijewski patterns to predict the bankruptcy of the companies listed in Tehran Stock Exchange" Master's thesis, Islamic Azad University, Central Tehran Branch.

Tehrani, S., 2005, "Business Law", Volume IV, Ghoghnoos Publishing.

Hajiha, Z., 2005, "the collapse of the company, causes and its stages, the study of bankruptcy legal system in Iran and the world", the auditor, No. 29.

Khaki, GH, 2008, "Research Methodology with a view to the dissertation", Fourth Edition, Baztab Publications.

Delaware, A., 2005, "theoretical and practical research in the humanities and social sciences", Fourth Edition, Roshd Publications.

Rasoulzadeh, M., 2001, "Evaluation of Altman's model to predict the bankruptcy of the companies listed in Tehran Stock Exchange", Tadbir, No. 120.

Rostami, V, 2002, "the relationship between the relative ability of continuity and the ratio of P/E in the valuation of the company" MA thesis, University of Allameh Tabatabai. 
Sarmad, Z., et al., 2006, "Research Methods in the Behavioral Sciences", Thirteenth Edition, Agah Publications.

Auditing Organization, 2008, "accounting and auditing principles".

Shaghaghi Nejad, F., 2003, "bankruptcy laws in Iran", Journal of Accounting, the ninth year.

Sheikh, KH, 2007, "compared to the models of Ohlson, Altmanand Zavgin to predict bankruptcy of the companies listed in Tehran Stock Exchange" Master's thesis, Islamic Azad University, Central Tehran Branch.

Shabahang, R, 2008, "Financial Management", Volume I, Fifth Edition, Auditing Organization Publications, publication 92.

Alikhani, M., 2006, "Evaluation of bankruptcy models in Tehran Stock Exchange" Master's thesis, Islamic Azad University, Science and Research Branch.

Asgari, H., 2008, "Review of performance patterns of Springate, Zavgin and Falmer to predict bankruptcies of listed companies in Tehran Stock Exchange" Master's thesis, Islamic Azad University of Central Tehran.

Alamshahi, A., 2007, " investigate the predict ability ofZavgin model and relative valuation approach to evaluate the bankruptcy of the companies listed in Tehran Stock Exchange" Master's thesis, Islamic Azad University, Central Tehran Branch.

M. Fakhri Husein, El (2014), "Precision of the models of Altman, Springate, Zmijewski, and Grover for predicting the financial distress ". Journal of Economics, Business, and Accountancy Ventura Vol. 17, No. 3, December 2014, pages 405 - 416.

Altman, El (1968), "Financial ratios, discriminant analysis and the prediction of corporate bankruptcy". The journal of finance, 23 (4).

Beaver, WH (1966), "Financial ratios as predictors of failure". Journal of Accounting Research, 4, Empirical Research in Accounting: selected studies, (supplement).

Deakin, E.B. (1972), "A discriminant analysis of predictors of Business Failure". Journal of Accounting Research, 10 (1).

Horrigan, JO (1968), "A short history of financial ratio analysis". The Accounting Review.

Mckee, TE, \& Greenstein, M. (2000), Predicting bankruptcy using recursive partitioning and a realistically proportioned date set ". Journal of forecasting, 19 (3).

Min H. Jae, \& Lee C. Young (2005), "Bankruptcy prediction using support vector machine with optimal choice of kernel function parameters". Expert Systems with Applications, 28.

Ohlson, J.A. (1980), "Financial Ratios and the probabilistic prediction of Bankruptcy". Journal of Accounting Research (Spring).

Paul PM Pompe, Jan bilderbeek (2002), "The prediction of bankruptcy of small- and medium- sized industrial firm", Journal of Accounting Research.

Shirata Cindy Yoshiko (1998). "Financial Ratios as Predictors of Bankruptcy in Japan": An Enprical Research.

Springate, Gord, L.V. (1978). "Predicting the possibility of failure in a Canadian firm". Unpublished MBA Research Project, Simoon Fraser university, junuary.

Zmijewski Mark.E (1984). Method logical Issues Relate to the Estimation of Finantion of Financial Distress Prediction Models ". Journal of Accounting Research vol 22 supplement. 